\title{
Inspiratory threshold loading reduces lipoperoxidation in obese and normal-weight subjects
}

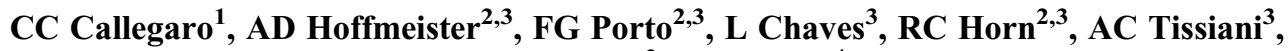 \\ PDA Bianchi ${ }^{3}$, JA Taylor ${ }^{4}$ \\ ${ }^{1}$ Laboratory of Physiology and Rehabilitation, Federal University of Santa Maria (UFSM), Santa Maria, Brazil \\ ${ }^{2}$ Postgraduate Program in Integral Attention to Health (PPGAIS-UNIJUI/UNICRUZ), Ijuí, Brazil \\ ${ }^{3}$ University of Cruz Alta, Cruz Alta, Brazil \\ ${ }^{4}$ Harvard Medical School, Boston, MA, USA
}

Received: May 14, 2018

Accepted: February 28, 2019

\begin{abstract}
Obesity is related to increased oxidative stress. Although low-intensity physical exercise reduces oxidative stress, obese subjects may show exercise intolerance. For these subjects, inspiratory threshold loading could be an alternative tool to reduce oxidative stress. We investigated the effects of inspiratory threshold loading on biomarkers of oxidative stress in obese and normal-weight subjects. Twenty obese (31.4 \pm 6 years old, 10 men and 10 women, $\left.37.5 \pm 4.7 \mathrm{~kg} / \mathrm{m}^{2}\right)$ and 20 normal-weight $\left(29.4 \pm 8\right.$ years old, 10 men and 10 women, $\left.23.2 \pm 1.5 \mathrm{~kg} / \mathrm{m}^{2}\right) \mathrm{subjects}$ matched for age and gender participated in the study. Maximal inspiratory pressure (MIP) was assessed by a pressure transducer. Blood sampling was performed before and after loading and control protocols to assess thiobarbituric acid reactive substances (TBARS), protein carbonylation, and reduced glutathione. Inspiratory threshold loading was performed at $60 \%$ MIP and maintained until task failure. The 30 -min control protocol was performed at $0 \mathrm{cmH}_{2} \mathrm{O}$. Our results demonstrated that inspiratory threshold loading reduced TBARS across time in obese $(6.21 \pm 2.03$ to $4.91 \pm 2.14 \mathrm{nmol} \mathrm{MDA} / \mathrm{ml})$ and normal-weight subjects $(5.60 \pm 3.58$ to $4.69 \pm 2.80 \mathrm{nmol} \mathrm{MDA} / \mathrm{ml} ; p=0.007)$, but no change was observed in protein carbonyls and glutathione in both groups. The control protocol showed no significant changes in TBARS and protein carbonyls. However, reduced glutathione was increased across time in both groups (obese: from $0.50 \pm 0.37$ to $0.56 \pm 0.35 \mu \mathrm{mol} \mathrm{GSH} / \mathrm{ml}$; normal-weight: from $0.61 \pm 0.11$ to $0.81 \pm 0.23 \mu \mathrm{mol} \mathrm{GSH} / \mathrm{ml} ; p=0.002$ ). These findings suggest that inspiratory threshold loading could be potentially used as an alternative tool to reduce oxidative stress in both normal-weight and obese individuals.
\end{abstract}

Keywords: oxidative stress, obesity, inspiratory exercise, inspiratory muscle strength, thiobarbituric acid reactive substances

\section{Introduction}

Obesity increases the risk of almost all causes of mortality (26). Greater body fat impairs metabolic function and induces the production of reactive oxygen species (ROS), which decreases antioxidant defenses and leads to oxidative damage (28). Oxidative stress can be directly evaluated through free radical production (21) or indirectly via end products of oxidative damage to lipids (9) and proteins (18). For example, thiobarbituric acid reactive substances (TBARS) reflect oxidative damage in lipids (24), whereas protein carbonyls are representative of oxidative damage to proteins (18). On the other hand, ROS-mediated

Corresponding author: Carine Cristina Callegaro, $\mathrm{PhD}$

Laboratory of Physiology and Rehabilitation, Federal University of Santa Maria (UFSM)

Av. Roraima, no. 1000, Cidade Universitária, Centro de Ciências da Saúde

Bairro Camobi, Santa Maria, RS, CEP: 97105-900, Brazil

Phone: +55 559914 6712; E-mail: ccallegaro84@gmail.com 
oxidative damage can be inhibited by the antioxidant state and this can be evaluated by antioxidative glutathione (GSH) (3).

It appears that an acute exercise bout may impact oxidative stress. A recently published study found decreased TBARS, while catalase activity, an antioxidant that combats oxidative stress, was increased $1 \mathrm{~h}$ after high-intensity intermittent exercise in obese middle-aged males (27). This finding could be clinically relevant because oxidative stress in obese subjects is related to the development of cardiovascular diseases (28). In contrast, previous studies have shown that both intensive aerobic exercise (37) and resistance exercise (34) result in increased lipid peroxidation in obese compared to non-obese individuals. Interestingly, low-intensity aerobic exercise (performed at $50 \%$ of the heart rate reserve) decreases the 8-iso prostaglandin F2 $\alpha$, an important biomarker of oxidative stress (13).

It also appears that inspiratory exercise has an acute effect on oxidative stress. In rats, inspiratory loading at 50\% maximal inspiratory pressure (MIP) for $1 \mathrm{~h}$ reduced nitrite and nitrate (33) and increased oxidative stress in the diaphragm (30). In dogs, high-intensity inspiratory load above $38 \%$ MIP maintained for $2 \mathrm{~h}$ increased protein tyrosine nitration and carbonylation in the diaphragm muscle, an effect abolished by the administration of the antioxidant acetylcysteine (4). Based on the fact that diaphragmatic breathing (14) and low-intensity physical exercise acutely decrease oxidative stress in humans (13), we hypothesized that inspiratory threshold loading would reduce oxidative stress. Since obesity is associated with increased oxidative stress $(8,38)$ and lower adherence to physical activity (11), inspiratory threshold loading could be an alternative tool to reduce oxidative stress. The objective of this study was to investigate the acute effects of inspiratory threshold loading on oxidative stress in obese and normal-weight subjects.

\section{Materials and Methods}

\section{Ethical approval}

The study was approved by the Ethics Committee in Research of the University of Cruz Alta (approval no. CAAE: 51573315.7.0000.5322) and clinical trial registry number NCT03056937. All volunteers provided written and verbal informed consent.

\section{Participants}

Twenty obese [10 men and 10 women; mean \pm standard deviation (SD): age, $31.4 \pm 6$ years and body mass index (BMI), $\left.37.5 \pm 4.7 \mathrm{~kg} / \mathrm{m}^{2}\right]$ and 20 normal-weight subjects (10 men and 10 women; mean \pm SD: age, $29.4 \pm 8$ years and BMI, $\left.23.2 \pm 1.5 \mathrm{~kg} / \mathrm{m}^{2}\right)$. All individuals were sedentary and non-smokers, free of cardiovascular, pulmonary, neuromuscular, and infectious diseases. All experimental testing took place at the Laboratory of Physiology, University of Cruz Alta, Brazil.

\section{Study design}

Participants attended the laboratory on three occasions (one familiarization session and two experimental sessions). One week prior to the study, subjects were familiarized with the protocols. All subjects were blinded to the inspiratory load performed (POWERbreathe International, Ltd., Southam, United Kingdom). The subjects were oriented to achieve the breathing frequency (15 breaths/min) and duty cycle [inspiratory time (IT)/total breathing time $($ Ttot $)=0.75]$, guided by a computer-generated audio signal with distinct inspiratory and 
expiratory commands. On the day of the study, venous blood was taken after 15 min of resting and at the end of both the inspiratory threshold loading protocol and the control protocol for the analysis of markers of oxidative stress. The protocols were performed on different days in a random order.

\section{Study protocols}

Inspiratory threshold loading protocol. After $20 \mathrm{~min}$ of rest, the inspiratory muscle strength was determined via MIP measured by a pressure transducer connected to a system with two unidirectional valves (DHD Inspiratory Muscle Trainer, Chicago, IL, USA). MIP was determined during deep inspiration from residual volume against an occluded airway with a minor air leak $(2 \mathrm{~mm})(1,2)$. It was assessed 12 times to obtain 6 measurements with less than $10 \%$ variation in the highest peak pressure sustained for $1 \mathrm{~s}(6)$. Inspiratory muscle strength was expressed in $\mathrm{cmH}_{2} \mathrm{O}(25)$.

Inspiratory threshold loading protocol until task failure was induced by breathing against an inspiratory load of $60 \%$ MIP with a prolonged duty cycle $(\mathrm{IT} / \mathrm{Ttot}=0.75)$. Each subject wore a nose clip and breathed continuously through a POWERbreathe Plus Medium Resistance Inspiratory Muscle Trainer on the inspiratory side. During each inspiratory effort, subjects were instructed to achieve the preset target inspiratory pressure $(60 \% \mathrm{MIP})$ traced on the screen and sustain it during inspiration. Breathing frequency ( 15 breaths $/ \mathrm{min}$ ) and duty cycle $(\mathrm{IT} / \mathrm{Ttot}=0.75)$ were guided by a computer-generated audio signal with distinct inspiratory and expiratory commands. The criterion for task failure was defined as the inability to generate the target inspiratory pressure for three consecutive inspiratory efforts after which the subjects were instructed to continue to attempt to reach the target for additional $1 \mathrm{~min}(29)$.

\section{Control protocol}

Subjects breathed continuously through a POWERbreathe Classic Medium Resistance Inspiratory Muscle Trainer (Southam, United Kingdom) without inspiratory load $\left(0 \mathrm{cmH}_{2} \mathrm{O}\right)$ for $30 \mathrm{~min}$ with the same breathing pattern performed during inspiratory threshold loading protocol (29).

\section{Oxidative stress analysis}

Systemic lipid peroxidation was determined by the plasma levels of TBARS according to the methods described by Jentzsch et al. (15). First, $220 \mu$ of plasma was mixed with $1 \mathrm{ml}$ of phosphoric acid, $550 \mu \mathrm{l}$ of distilled water, and $250 \mu \mathrm{l}$ of thiobarbituric acid. The samples were incubated for $45 \mathrm{~min}$ at $95{ }^{\circ} \mathrm{C}$, and readings were taken in a visible spectrophotometer at $532 \mathrm{~nm}$. The results were expressed as nmol MDA/ml plasma.

Protein carbonyl levels were determined using the technique described by Levine et al. (22). Initially, $300 \mu \mathrm{l}$ of plasma was diluted in $2.7 \mathrm{ml}$ of HEPES. A $50 \mu \mathrm{l}$ sample of this dilution was used to determine the total protein with Labtest ${ }^{\circledR}$ commercial kit (Lagoa Santa, Brazil), and $500 \mu \mathrm{l}$ of the same diluted plasma was used to determine the protein carbonylated using $250 \mu \mathrm{l}$ of $10 \%$ trichloroacetic acid, $2 \mathrm{~N}$ hydrochloric acid, 2, 4-dinitrophenylhydrazine, and sodium dodecyl sulfate $3 \%$, realizing a blank for each sample. The readings of the tests and the whites of the tests were performed in a visible spectrophotometer at $370 \mathrm{~nm}$. The results were expressed as nmol carbonyl/mg protein.

Reduced GSH was determined by the technique described by Ellman (10). In brief, it was used a solution containing $100 \mu \mathrm{l}$ of plasma, $850 \mu \mathrm{l}$ of potassium phosphate buffer (TFK) 
$1 \mathrm{M}$ at $\mathrm{pH} 7.4$, and $50 \mu \mathrm{l}$ of 5,5'-dithiobis-(2-nitrobenzoic acid) (DTNB). The procedure was performed in an ice bath. The DTNB was mixed only during reading, in a visible spectrophotometer at $412 \mathrm{~nm}$. The results were expressed as $\mu \mathrm{mol} \mathrm{GSH} / \mathrm{ml}$.

\section{Statistical analysis}

Data were expressed as mean and SD. The analysis was performed using SPSS software, version 22 (New York, USA). The data were normally distributed as determined by the Kolmogorov-Smirnov test. Analysis of variance for repeated measures was used to determine the effects of inspiratory threshold loading on oxidative stress in obese individuals and in normal-weight individuals. Significance was set at $p<0.05$.

\section{Results}

As expected, obese subjects had higher body weights and BMIs than normal-weight subjects (Table I). Fasting glucose, triglycerides, and total cholesterol were higher in obese than in normal-weight subjects. Inspiratory muscle strength did not differ between obese $\left(120 \pm 45 \mathrm{cmH}_{2} \mathrm{O}\right)$ and normal-weight subjects $\left(118 \pm 31 \mathrm{cmH}_{2} \mathrm{O}, p=0.81\right)$.

The inspiratory threshold loading at $60 \%$ MIP similarly reduced the levels of TBARS across time in obese (from $6.21 \pm 2.03$ to $4.91 \pm 2.14 \mathrm{nmol} \mathrm{MDA} / \mathrm{ml}$ ) and normal-weight subjects (from $5.60 \pm 3.58$ to $4.69 \pm 2.80 \mathrm{nmol} \mathrm{MDA} / \mathrm{ml}$; Fig. 1). There was no effect of gender on TBARS responses to inspiratory threshold loading; when comparing men versus women, regardless of the presence of obesity, TBARS was reduced across time $(p=0.008)$ similarly in men and women (women: from $4.96 \pm 2$ to $3.87 \pm 1.8 \mathrm{nmol} \mathrm{MDA} / \mathrm{ml}$; men: from $6.81 \pm 3.5$ to $5.81 \pm 2.7 \mathrm{nmol} \mathrm{MDA} / \mathrm{ml}$ ). However, men did have greater TBARS at baseline ( $p=0.01$; Fig. 2). There was not enough statistical power to evaluate the effects of inspiratory threshold loading in gender subgroups of obese and normal-weight. Protein carbonyls remained unchanged (obese: from $2.19 \pm 1.70$ to $2.6 \pm 2.8 \mathrm{nmol}$ protein carbonyl $/ \mathrm{mg}$; normal-weight: from $2.68 \pm 1.69$ to $3.09 \pm 2.18 \mathrm{nmol}$ carbonyl/g protein, Fig. 3) as did

Table I. Clinical characteristics of obese and normal-weight individuals

\begin{tabular}{|l|c|c|c|}
\hline & Obese $(\boldsymbol{n}=\mathbf{2 0})$ & Normal-weight $(\boldsymbol{n}=\mathbf{2 0})$ & $\boldsymbol{p}$ \\
\hline Age (years) & $31.4 \pm 6$ & $29.4 \pm 8$ & 0.389 \\
\hline Gender (male/female) & $10 / 10$ & $10 / 10$ & $0.001^{*}$ \\
\hline Weight $(\mathrm{kg})$ & $107 \pm 18$ & $66 \pm 8$ & 0.879 \\
\hline Height $(\mathrm{m})$ & $1.68 \pm 0.8$ & $1.68 \pm 0.1$ & $0.001^{*}$ \\
\hline BMI $\left(\mathrm{kg} / \mathrm{m}^{2}\right)$ & $37.5 \pm 4.7$ & $23.2 \pm 1.5$ & $0.001^{*}$ \\
\hline Glycemia $(\mathrm{mg} / \mathrm{dl})$ & $93 \pm 13$ & $75.65 \pm 7.4$ & $0.013^{*}$ \\
\hline Triglycerides $(\mathrm{mg} / \mathrm{dl})$ & $128 \pm 53$ & $91 \pm 32$ & $0.046^{*}$ \\
\hline Total cholesterol $(\mathrm{mg} / \mathrm{dl})$ & $166 \pm 32$ & $147 \pm 23$ & 0 \\
\hline
\end{tabular}

BMI: body mass index.

$* p<0.05$ 

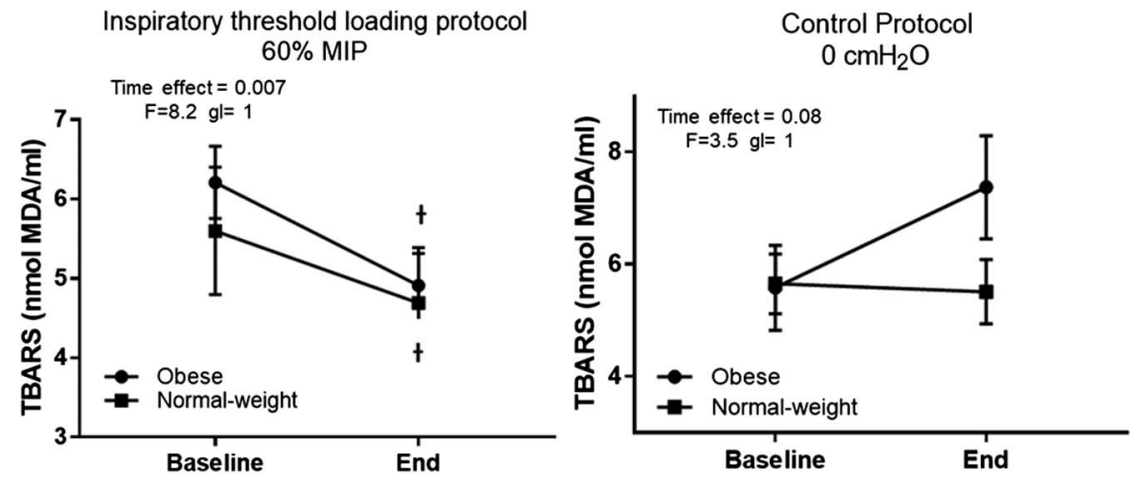

Fig. 1. Effects of inspiratory threshold loading on TBARS. Data were expressed as mean and standard deviation. Inspiratory threshold loading reduced baseline TBARS in obese and normal-weight subjects. Measured values were not significantly changed in the control protocol. $\dagger p<0.05$ baseline vs. end

\section{Inspiratory threshold loading protocol $60 \%$ MIP by gender}

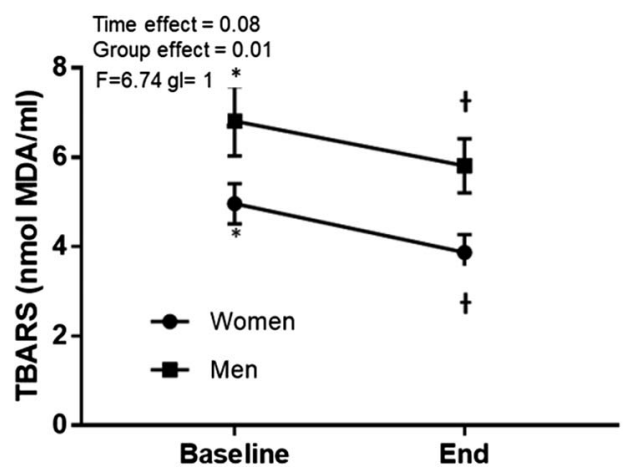

Inspiratory threshold loading protocol $60 \%$ MIP

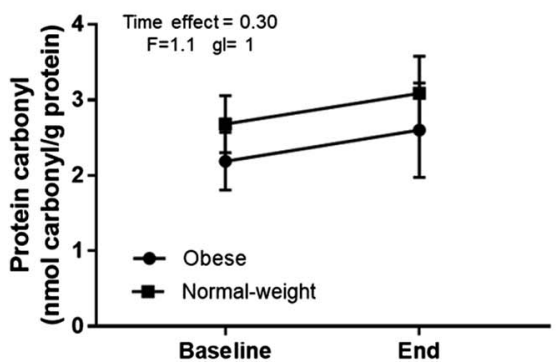

Fig. 2. Effects of inspiratory threshold loading on TBARS related to gender. Data were expressed as mean and standard deviation. Inspiratory threshold loading reduced TBARS similarly in men and women. Men did have greater TBARS at baseline. ${ }^{*} p<0.05$ woman vs. men. $\dagger p<0.05$ baseline vs. end

\section{Control Protocol \\ $0 \mathrm{cmH}_{2} \mathrm{O}$}

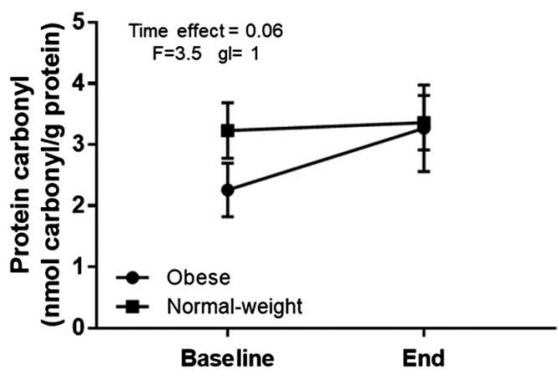

Fig. 3. Effects of inspiratory threshold loading on protein carbonyl. Data were expressed as mean and standard deviation. Protein carbonyl was not significantly changed by inspiratory threshold loading and control protocol 

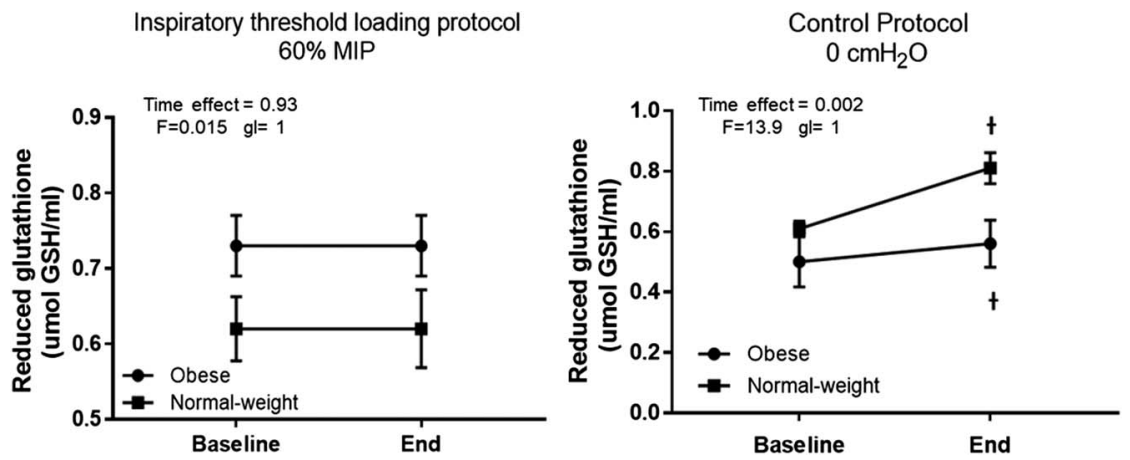

Fig. 4. Effects of inspiratory threshold loading on reduced glutathione. Data were expressed as mean and standard deviation. Inspiratory threshold loading did not change reduced glutathione. Control protocol induced an increase in reduced glutathione in obese and normal-weight subjects. $\uparrow p<0.05$ baseline vs. end

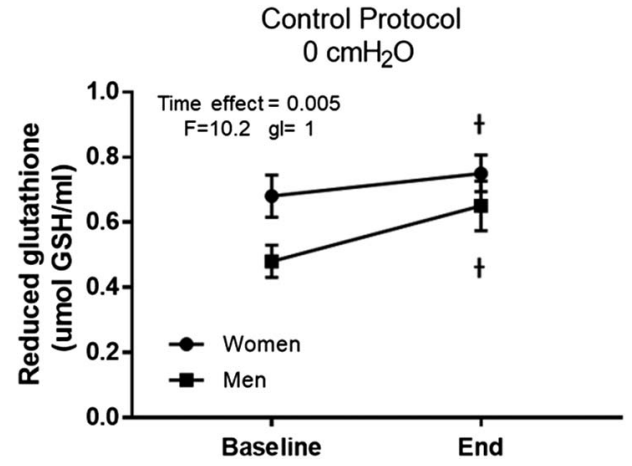

Fig. 5. Effects of control protocol on reduced glutathione related to gender. Data were expressed as mean and standard deviation. Control protocol induced an increase in reduced glutathione similar in men and women. $\dagger p<0.05$ baseline vs. end

reduced GSH (obese: from $0.73 \pm 0.18$ to $0.73 \pm 0.18 \mu \mathrm{mol} \mathrm{GSH} / \mathrm{ml}$; normal-weight: from $0.62 \pm 0.19$ to $0.62 \pm 0.23 \mu \mathrm{mol} \mathrm{GSH} / \mathrm{ml}$; Fig. 4). There was insufficient statistical power to analyze the effect of gender on protein carbonyls and reduced GSH responses to inspiratory threshold loading regardless of the presence of obesity.

As expected, the control protocol performed without inspiratory load showed no significant changes in TBARS (obese: from $5.58 \pm 3.38$ to $7.37 \pm 4.1 \mathrm{nmol} \mathrm{MDA} / \mathrm{ml}$; normal-weight: from $5.65 \pm 2.38$ to $5.51 \pm 2.55 \mathrm{nmol} \mathrm{MDA} / \mathrm{ml}$; Fig. 1) and protein carbonyls (obese: from $2.26 \pm 1.96$ to $3.27 \pm 3.17 \mathrm{nmol}$ protein carbonyl $/ \mathrm{mg}$; normal-weight: from $3.23 \pm 2.03$ to $3.36 \pm 1.99 \mathrm{nmol}$ carbonyl mg protein; Fig. 3). For the control protocol, there was not enough statistical power to analyze the effects of gender on TBARS and protein carbonyls.

However, reduced GSH was increased across time $(p=0.002)$ in both groups (obese: from $0.50 \pm 0.37$ to $0.56 \pm 0.35 \mu \mathrm{mol} \mathrm{GSH} / \mathrm{ml}$; normal-weight: from $0.61 \pm 0.11$ to $0.81 \pm 0.23 \mu \mathrm{mol} \mathrm{GSH} / \mathrm{ml}$; Fig. 4). The control protocol induced a similar increase in reduced GSH across time $(p=0.005)$ in men and women (women: from $0.68 \pm 0.29$ to $0.75 \pm 0.25 \mu \mathrm{mol} \mathrm{GSH} / \mathrm{ml}$; men: from $0.48 \pm 0.22$ to $0.65 \pm 0.34 \mu \mathrm{mol} \mathrm{GSH} / \mathrm{ml}$; Fig. 5). 


\section{Discussion}

This study demonstrates that inspiratory threshold loading reduces lipid peroxidation in both obese and normal-weight subjects. This finding suggests that acute inspiratory exercise may inhibit oxidative stress related to reduction in lipid oxidation.

In agreement with our findings, high-intensity intermittent physical exercise decreased TBARS in obese middle-aged males (27) and walking exercise decreases the 8-iso prostaglandin F2 $\alpha$ (13), a biomarker of oxidative stress, in type-2 diabetic patients. However, the effects of acute physical exercise on oxidative stress biomarkers are divergent across studies. For example, maximal graded treadmill exercise (37) and moderate-intensity aerobic and resistance exercise (34) result in greater increases in lipid peroxidation in obese compared to non-obese individuals. Perhaps, exercise involving a greater muscle mass contributes to increased oxidative stress. However, a recent study shows that high-intensity interval exercise on either treadmill or cycle ergometer induced a similar reduction in TBARS postexercise in young men (19), despite treadmill exercise involving greater muscle mass. To our knowledge, this is the first study to investigate the effects of inspiratory threshold loading on oxidative stress in humans. This type of exercise differs from whole-body exercise and involves far lesser muscle mass. In addition, diaphragmatic muscle appears to be better protected from oxidative stress than hind limb skeletal muscles (32).

The effects of inspiratory threshold loading on oxidative stress have been only investigated in animals $(4,30)$. A previous study in humans showed that diaphragmatic breathing (without inspiratory load) reduced malondialdehyde and superoxide dismutase, both markers of oxidative stress (14). This finding is in agreement with this study, in which inspiratory threshold loading performed at $60 \%$ MIP reduced systemic lipoperoxidation (TBARS) in obese and normal-weight humans. Although the mechanism involved in the reduction of lipoperoxidation after inspiratory exercise remains unknown, we suppose that there is a relationship between reduction in lipid peroxidation and oxidative capacity of the diaphragm (36). In fact, aerobically trained rats showed a $30 \%$ lower level of lipid peroxides compared to sedentary rats after a fatiguing diaphragm protocol (35).

As expected, in this study, the control protocol did not significantly change TBARS. However, reduced GSH was increased in obese and normal-weight subjects after the control protocol. In a previous study, diaphragmatic breathing improved GSH and vitamin $\mathrm{C}$ in patients with type-2 diabetes (14). In addition, an earlier interventional yoga program consisting of prayers, asana, pranayama, and meditation performed for 6 months increased total antioxidant status in healthy individuals (31). In this study, controlled breathing acutely increased the reduced GSH, which may be analogous to altered breathing during yoga.

Gender could affect oxidative stress (16), as demonstrated in this study, by lower levels of TBARS in women compared to men at baseline. However, inspiratory threshold loading induced similar reduction of TBARS in men and women. This finding is in agreement with a previous study, in which changes of oxidative stress in response to exercise were similar in men and women (12).

In this study, oxidative stress biomarkers were similar in obese and normal-weight subjects at baseline in agreement with a previous study (37). Interestingly, metabolically healthy normal-weight and metabolically healthy obese subjects showed similar changes in TBARS after acute aerobic exercise (23). Hence, other comorbidities associated with obesity may exacerbate oxidative damage in lipids and proteins and reduce the antioxidant state. A previous study showed that advanced oxidation protein products were increased only in obese 
patients with diabetes compared to obese prediabetics and healthy controls (17). Advanced oxidation protein products seem to be related to central obesity, triglycerides, lipid peroxidation, and insulin (20). In addition, metabolic syndrome seems to increase lipid peroxidation (7) and carbonyl protein (5). These data suggest that increased oxidative stress in obese subjects could be related to metabolic comorbidities. However, in this study, the baseline values of TBARS and protein carbonyls were not influenced by glycemia, cholesterol, and blood pressure.

Based on the fact that inspiratory threshold loading acutely reduces lipid peroxidation, it is possible that long-term inspiratory exercise training may inhibit oxidative stress and provide clinical benefits for healthy individuals as well as patients with obesity.

\section{Conclusions}

Inspiratory threshold loading reduces lipid peroxidation in obese and normal-weight subjects. These findings suggest that inspiratory threshold loading could be potentially used as an alternative tool to reduce oxidative stress in both normal-weight and obese individuals.

\section{Acknowledgements}

The authors would like to thank all the volunteers that participated in this study. FGP was supported by a scholarship (PROBIC) from Fundação de Amparo à Pesquisa do Estado do Rio Grande do Sul (FAPERGS). This study was supported by the grant (PAPCT) from University of Cruz Alta, Brazil.

\section{Conflict of interest}

All authors declare no competing interests.

\section{REFERENCES}

1. American Thoracic Society/European Respiratory Society: ATS/ERS Statement on respiratory muscle testing. Am. J. Respir. Crit. Care Med. 166, 518-624 (2002)

2. Arena R, Cahalin LP: Evaluation of cardiorespiratory fitness and respiratory muscle function in the obese population. Prog. Cardiovasc. Dis. 56, 457-464 (2014)

3. Barbosa KBF, Costa NMB, Alfenas RCG, De Paula SO, Minim VPR, Bressan J: Estresse oxidativo: conceito, implicações e fatores modulatórios [Oxidative stress: concept, implications and modulating factors]. Rev. Nutr. 23, 629-643 (2010)

4. Barreiro E, Gáldiz JB, Marinán M, Alvarez FJ, Hussain SN, Gea J: Respiratory loading intensity and diaphragm oxidative stress: N-acetyl-cysteine effects. J. Appl. Physiol (1985). 100, 555-563 (2006)

5. Baturin AK, Pogozheva AV, Akol'zina SE, Kodentsova VM, Vrzhesinskaia OA, Beketova NA, Pereverzeva OG: Peculiarities of vitamin status in men and women with cardiovascular disease and obesity. Vopr. Pitan. 81, 58-64 (2012)

6. Callegaro CC, Ribeiro JP, Tan CO, Taylor JA: Attenuated inspiratory muscle metaboreflex in endurance-trained individuals. Respir. Physiol. Neurobiol. 177, 24-29 (2011)

7. Conti FF, Brito JO, Bernardes N, Dias DS, Sahnches IC, Malfitano C, Llesuy SF, Irigoyen MC, Angelis KD: Cardiovascular autonomic dysfunction and oxidative stress induced by fructose overload in an experimental model of hypertension and menopause. BMC Cardiovasc. Disord. 14, 185 (2014)

8. D’Archivio M, Annuzzi G, Varì R, Filesi C, Giacco R, Scazzocchio B, Santangelo C, Giovannini C, Rivellese AA, Masella R: Predominant role of obesity/insulin resistance in oxidative stress development. Eur. J. Clin. Invest. 42, 70-78 (2012) 
9. Dorjgochoo T, Gao YT, Chow WH, Shu XO, Yang G, Cai Q, Rothman N, Cai H, Li H, Deng X, Franke A, Roberts LJ, Milne G, Zheng W, Dai Q: Major metabolite of F2-isoprostane in urine may be a more sensitive biomarker of oxidative stress than isoprostane itself. Am. J. Clin. Nutr. 96, 405-414 (2012)

10. Ellman GL: Tissue sulfhydryl groups. Arch. Biochem. Biophys. 82, 70-77 (1959)

11. Galvim AL, Oliveira IM, Martins TV, Vieira LM, Cerri NC, Cezar NOC, Pedroso RV, Gomes GAO: Adherence, adhesion, and dropout reasons of a physical activity program in a high social vulnerability context. J. Phys. Act. Health. 16, 149-156 (2019)

12. Goldfarb AH, McKenzie MJ, Bloomer RJ: Gender comparisons of exercise-induced oxidative stress: influence of antioxidant supplementation. Appl. Physiol. Nutr. Metab. 32, 1124-1131 (2007)

13. Haxhi J, Leto G, di Palumbo AS, Sbriccoli P, Guidetti L, Fantini C, Buzzetti R, Caporossi D, Di Luigi L, Sacchetti M: Exercise at lunchtime: effect on glycemic control and oxidative stress in middle aged men with type 2 diabetes. Eur. J. Appl. Physiol. 116, 573-582 (2016)

14. Hegde SV, Adhikari P, Subbalakshmi NK, Nandini M, Rao GM, D’souza V: Diaphragmatic breathing exercise as a therapeutic intervention for control of oxidative stress in type 2 diabetes mellitus. Complement. Ther. Clin. Pract. 18, 151-153 (2012)

15. Jentzsch AM, Bachmann H, Fürst P, Biesalski HK: Improved analysis of malondialdehyde in human body fluids. Free Radic. Biol. Med. 20, 251-256 (1996)

16. Kander MC, Cui Y, Liu Z: Gender difference in oxidative stress: a new look at the mechanisms for cardiovascular diseases. J. Cell Mol. Med. 21, 1024-1032 (2017)

17. Koçak H, Oner-Iyidoğan Y, Gürdöl F, Oner P, Süzme R, Esin D, Işsever H: Advanced oxidation protein products in obese women: its relation to insulin resistance and resistin. Clin. Exp. Med. 7, 173-178 (2007)

18. Komosinska-Vassev K, Olczyk P, Winsz-Szczotka K, Klimek K, Olczyk K: Plasma biomarkers of oxidative and AGE-mediated damage of proteins and glycosaminoglycans during healthy ageing: a possible association with ECM metabolism. Mech. Ageing Dev. 133, 538-548 (2012)

19. Kouvelioti R, LeBlanc P, Falk B, Ward WE, Josse AR, Klentrou P: Effects of high-intensity interval running versus cycling on sclerostin, and markers of bone turnover and oxidative stress in young men. Calcif. Tissue Int. 104, 582-590 (2019)

20. Krzystek-Korpacka M, Patryn E, Boehm D, Berdowska I, Zielinski B, Noczynska A: Advanced oxidation protein products (AOPPs) in juvenile overweight and obesity prior to and following weight reduction. Clin. Biochem. 41, 943-949 (2008)

21. Lee MC: Assessment of oxidative stress and antioxidant property using electron spin resonance (ESR) spectroscopy. J. Clin. Biochem. Nutr. 52, 1-8 (2013)

22. Levine RL, Garland D, Oliver CN, Amici A, Climent I, Lenz AG, Ahn BW, Shaltiel S, Stadtman ER: Determination of carbonyl content in oxidatively modified proteins. Methods Enzymol. 186, 464-478 (1990)

23. Lwow F, Dunajska K, Milewicz A, Jedrzejuk D, Kik K, Szmigiero L: Effect of moderate-intensity exercise on oxidative stress indices in metabolically healthy obese and metabolically unhealthy obese phenotypes in postmenopausal women: a pilot study. Menopause. 18, 646-653 (2011)

24. Medeiros Nda S, de Abreu FG, Colato AS, de Lemos LS, Ramis TR, Dorneles GP, Funchal C, Dani C: Effects of concurrent training on oxidative stress and insulin resistance in obese individuals. Oxid. Med. Cell. Longev. 2015, $697181(2015)$

25. Neder JA, Andreoni S, Lerario MC, Nery LE: Reference values for lung function tests. II. Maximal respiratory pressures and voluntary ventilation. Braz. J. Med. Biol. Res. 32, 719-727 (1999)

26. Ogden CL, Yanovski SZ, Carroll MD, Flegal KM: The epidemiology of obesity. Gastroenterology 132, 2087-2102 (2007)

27. Parker L, Stepto NK, Shaw CS, Serpiello FR, Anderson M, Hare DL, Levinger I: Acute high-intensity interval exercise-induced redox signaling is associated with enhanced insulin sensitivity in obese middle-aged men. Front. Physiol. 7, 411 (2016)

28. Savini I, Catani MV, Evangelista D, Gasperi V, Avigliano L: Obesity-associated oxidative stress: strategies finalized to improve redox state. Int. J. Mol. Sci. 14, 10497-538 (2013)

29. Sheel AW, Derchak PA, Morgan BJ, Pegelow DF, Jacques AJ, Dempsey JA: Fatiguing inspiratory muscle work causes reflex reduction in resting leg blood flow in humans. J. Physiol. 537, 277-289 (2001)

30. Sigala I, Zacharatos P, Toumpanakis D, Michailidou T, Noussia O, Theocharis S, Roussos C, Papapetropoulos A, Vassilakopoulos T: MAPKs and NF- $\mathrm{B}$ differentially regulate cytokine expression in the diaphragm in response to resistive breathing: the role of oxidative stress. Am. J. Physiol. Regul. Integr. Comp. Physiol. 300, R1152-R1162 (2011) 
31. Sinha S, Singh SN, Monga YP, Ray US: Improvement of glutathione and total antioxidant status with yoga. J. Altern. Complement. Med. 13, 1085-1090 (2007)

32. Talarmin H, Derbré F, Lefeuvre-Orfila L, Léon K, Droguet M, Pennec JP, Giroux-Metgès MA: The diaphragm is better protected from oxidative stress than hindlimb skeletal muscle during CLP-induced sepsis. Redox Rep. 22, 218-226 (2017)

33. Vassilakopoulos T, Govindaraju K, Parthenis D, Eidelman DH, Watanabe Y, Hussain SN: Nitric oxide production in the ventilatory muscles in response to acute resistive loading. Am. J. Physiol. Lung Cell. Mol. Physiol. 292, L1013-L1022 (2007)

34. Vincent HK, Morgan JW, Vincent KR: Obesity exacerbates oxidative stress levels after acute exercise. Med. Sci. Sports Exerc. 36, 772-779 (2004)

35. Vincent HK, Powers SK, Demirel HA, Coombes JS, Naito H: Exercise training protects against contractioninduced lipid peroxidation in the diaphragm. Eur. J. Appl. Physiol. Occup. Physiol. 79, 268-273 (1999)

36. Vincent HK, Powers SK, Stewart DJ, Demirel HA, Shanely RA, Naito H: Short-term exercise training improves diaphragm antioxidant capacity and endurance. Eur. J. Appl. Physiol. 81, 67-74 (2000)

37. Vincent HK, Vincent KR, Bourguignon C, Braith RW: Obesity and postexercise oxidative stress in older women. Med. Sci. Sports Exerc. 37, 213-219 (2005)

38. Warolin J, Coenen KR, Kantor JL, Whitaker LE, Wang L, Acra SA, Roberts LJ 2nd, Buchowski MS: The relationship of oxidative stress, adiposity and metabolic risk factors in healthy Black and White American youth. Pediatr. Obes. 9, 43-52 (2014) 